\title{
Perbandingan Metode Koreksi Topografi Pada Citra Satelit Landsat 8 di Wilayah Gunung Telomoyo, Jawa Tengah
}

\author{
Tantri Utami Widhaningtyas ${ }^{*}$, Akbar Cahyadhi Pratama Putra ${ }^{2}$, Trida Ridho Fariz ${ }^{3}$ \\ ${ }^{1}$ Image Processing Departement PT. SMART, Tbk. Jakarta \\ ${ }^{2}$ GIS Technology Information \& Solution Department. PT. Best Agro International. Jakarta \\ ${ }^{3}$ Sekolah Pascasarjana. Universitas Gadjah Mada. Yogyakarta, Indonesia
}

\begin{tabular}{l} 
Article Info \\
\hline Article History \\
Dikirim 7 Januari 2020 \\
Diterima 20 Juni 2020 \\
Terbit 29 Juli 2020 \\
\hline
\end{tabular}

\section{Keywords:}

koreksi topografi;

C Correction; SCS $+\mathrm{C}$;

Landsat 8; DEMNAS

\begin{abstract}
Abstrak
Kondisi topografi mempengaruhi perbedaan besarnya energi sinar matahari yang ditangkap, dipantulkan balik dan diterima sensor penginderaan jauh. Hal ini membuat perlu dilakukan koreksi radiometri topografi pada proses pra pengolahan citra. Metode koreksi topografi terhitung banyak sedangkan penelitian terkait koreksi topografi ternilai cukup jarang dilakukan di Indoensia. Tujuan penelitan ini adalah membandingkan metode koreksi topografi. Adapun wilayah studi dalam penelitian ini adalah wilayah Gunung Telomoyo. Data yang digunakan dalam penelitian ini adalah citra satelit Landsat 8 dan DEMNAS. Adapun metode koreksi topografi yang diujikan dalam penelitian ini adalah metode koreksi topografi C Correction dan SCS+C. Hasil dari penelitian menunjukkan bahwa data DEMNAS dapat digunakan sebagai sumber data untuk koreksi radiometrik topografi. Metode koreksi topografi yang paling baik pada penelitian ini adalah metode SCS $+C$ dilihat dari kenampakan visual dan memiliki nilai standar deviasi terendah dibandingkan dengan metode $C$ Correction. Sehingga untuk wilayah dengan dominasi tutupan lahan hutan maka metode SCS $+\mathrm{C}$ bisa direkomendasikan. Koreksi topografi berguna dalam peningkatan akurasi perhitungan biomassa dan estimasi karbon di dataran tinggi menggunakan data penginderaan jauh.
\end{abstract}

\footnotetext{
*E-mail : tantriutamiw@gmail.com
Address : Jl.Boulevard Bar. Raya, Klp. Gading Bar., Kelapa Gading, Jakarta 14240 Indonesia
} 


\section{PENDAHULUAN}

Teknologi penginderaan jauh memiliki kemampuan untuk menyadap informasi permukaan bumi tanpa kontak langsung. Informasi permukaan bumi dari sensor penginderaan jauh berbentuk surface reflectance yang mana dipengaruhi oleh sudut datang, energi, kekasaran permukaan dan materi (Danoedoro, 2012). Semakin kasar suatu permukaan, energi yang dipantulkan dapat dihamburkan ke segala arah. Kondisi topografi juga mempengaruhi perbedaan besarnya energi sinar matahari yang ditangkap, dipantulkan balik dan diterima sensor penginderaan jauh (Umarhadi, 2017). Oleh karena itu sebelum melakukan pra-pengolahan citra perlu dilakukan koreksi topografi selain koreksi radiometrik (Jensen, 2005). Koreksi topografi ini dilakukan untuk wilayah yang memiliki kondisi topografi bergunung yang mana arah hadap lereng (aspect) dan kemiringan lereng (slope) sangat mempengaruhi kenampakan obyek. Selain itu, kondisi permukaan bumi memiliki pengaruh yang signifikan terhadap nilai pantulan spektral karena pada medan bergunung masalah yang ada lebih kompleks (Hugli \& Frei, 1983).

Metode koreksi topografi dalam penginderaan jauh cukup banyak. Metode koreksi topografi tersebut terdiri dari cosine, Civco two-stages, statistik-empiris, minnaert dan faktor $\mathrm{C}$, yang telah digunakan oleh banyak peneliti (Pimple et al, 2017; Vázquez-Jiménez et al, 2017; Soenen et al, 2005; Fan et al, 2014; Riano et al, 2003). Walaupun metodenya baragam, tetapi studi tentang koreksi topografi di Indonesia terhitung cukup jarang dilakukan. Penelitian terkini tentang koreksi topografi di Indonesia yaitu Kurniawan \& Danoedoro (2017) yang melakukan perbandingan metode koreksi topografi terhadap indeks vegetasi, tetapi DEM yang digunakan dalam penelitian tersebut adalah peta topografi AMS yang cukup sulit didapatkan. Penelitian Umarhadi \& Danoedoro (2019) menjawab limitasi dari penelitian Kurniawan \& Danoedoro
(2017) dengan membandingkan DEM yang mudah diakses di Indonesia seperti peta RBI, SRTM dan DEMNAS pada koreksi topografi, tetapi metode yang digunakan hanya metode $\mathrm{SCS}+\mathrm{C}$.

Berdasarkan capaian penelitian Kurniawan \& Danoedoro (2017) dan Umarhadi \& Danoedoro (2019), maka penelitian ini bertujuan untuk membandingkan metode koreksi radiometric topografi $C$ Correction dan SCS + C (Sun Canopy Sensor $+C$ ). Data DEM yang digunakan yang tersedia gratis di Indonesia yaitu DEMNAS. DEMNAS dipilih karena memiliki hasil yang lebih baik secara visual dan statistik dibandingkan SRTM dan peta RBI (Umarhadi \& Danoedoro, 2019). Gunung Telomoyo dipilih menjadi lokasi penelitian karena kondisi topografi di wilayah tersebut sangat beragam. Kawasan Gunung Telomoyo termasuk dalam Zona Solo, barisan Gunungapi Merapi - Telomoyo menempati ujung barat dari Zona Solo (Hutami dkk, 2014), secara relief terlihat terdiri dari topografi yang beragam dari datar, berbukit, bergelombang hingga bergunung. Adapun citra penginderaan jauh yang digunakan adalah Landsat 8 OLI. Landsat 8 OLI memiliki 9 Band, pada penelitian ini memanfaatkan saluran cirrus untuk mengurangi koreksi awan tipis.

\section{METODELOGI}

\section{Lokasi penelitian}

Penelitian ini dilakukan di Gunung Telomoyo yang berada di tiga kabupaten/ kota, yaitu Kabupaten Semarang, Kota Salatiga, dan Kota Magelang (Gambar 1). Luas lokasi penelitian ini adalah sebesar 325,2 $\mathrm{Km}^{2}$. Secara morfogenesa, lokasi penelitian sebagian besar terdiri dari pegunungan medan lava dan kaki gunungapi. Lokasi penelitian memikili tutupan lahan cukup yang beragam terutama lereng kebawah (sekitar Rawa Pening) yang didominasi oleh tutupan lahan berupa lahan pertanian, lahan terbuka dan vegetasi (Jaelani \& Putri, 2017; Sanjoto et al, 2020). Oleh karena itu, Kawa-
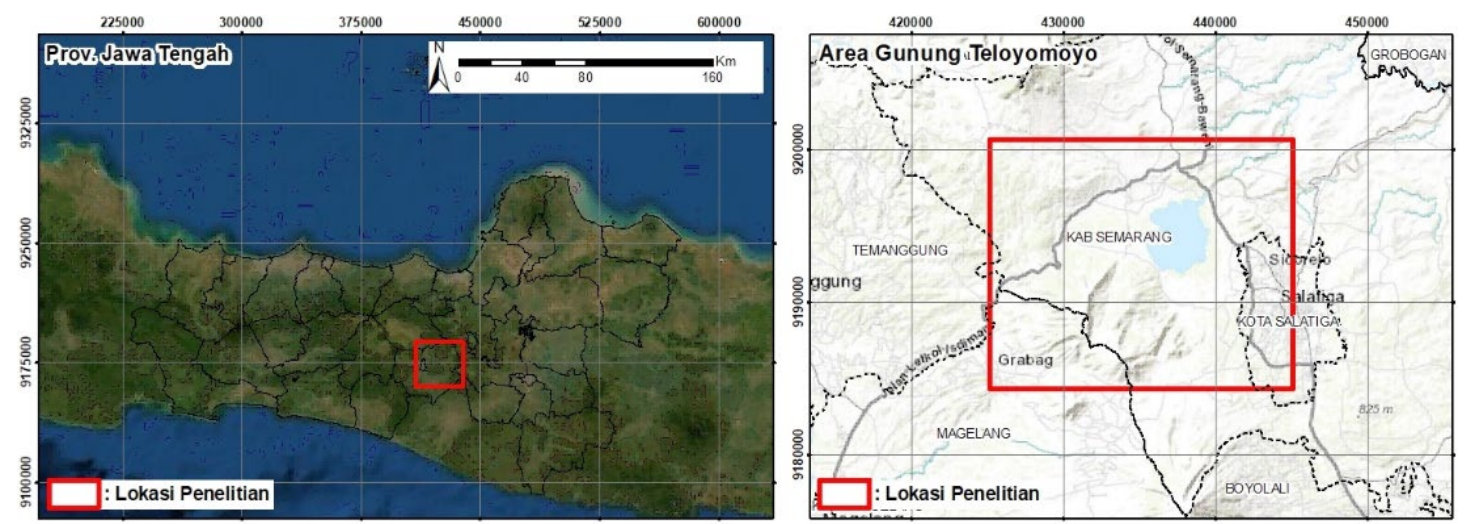

Gambar 1. Peta lokasi penelitian 
san Gunung Telomoyo kami nilai cocok sebagai lokasi penelitian untuk membandingkan kemampuan koreksi topografi.

\section{Pengolahan dan analisis data}

Data yang digunakan dalam penelitian ini adalah Landsat 8 OLI dan data DEMNAS. Sumber data Landsat di akses melalui website earthexplorer.usgs.gov sedangkan DEMNAS adalah data DEM (Digital Elevation Model) yang di akusisi oleh BIG untuk memetakan seluruh kondisi topografi di Indonesia, dengan mengakses tides.big.go.id/ DEMNAS/.

Citra Landsat yang digunakan untuk penelitian ini adalah citra Landsat 8 OLI Level L1T perekaman 13 September 2019 dengan Path 120 dan Row 65. Berdasarkan USGS (2019), citra Landsat 8 L1T ini sudah terkoreksi secara geometri. Dianovita \& Mahendra (2014) melakukan uji akurasi citra Landsat $8 \mathrm{~L} 1 \mathrm{~T}$ dan hasilnya adalah citra Landsat $8 \mathrm{~L} 1 \mathrm{~T}$ ini rata-rata memiliki akurasi kurang dari setengah piksel. Sehingga kami memutuskan untuk tidak melakukan koreksi geometri pada penelitian ini.

Sebelum dilakukan koreksi radiometrik citra satelit terlebih dahulu dikoreksi awan tipis yang mengganggu nilai pantulan spektral, koreksi awan tipis ini memanfaatkan saluran cirrus pada Citra Landsat 8. Menurut Ardiansyah (2015) koreksi cirrus dilakukan pada DN citra yang belum dikoreksi dengan memanfaatkan nilai minimum pada saluran cirrus pada persamaan.

\section{$D N{ }^{i j k t ~ t e r k o r e k s i ~}=D N{ }^{i j k}-a(D N$ cirrus $-D N$ mini- mum cirrus) $. . . \ldots \ldots \ldots \ldots \ldots \ldots \ldots . . . .1$}

Tahapan koreksi radiometri meliputi konversi nilai $\mathrm{DN}$ menjadi sensor radiance dan Top of Atmosphere Reflectance (USGS, 2013). Selanjutnya adalah koreksi topografi yang mana membutuhkan 2 data yaitu citra yang akan dikoreksi dan citra iluminasi matahari. Citra yang akan dilakukan koreksi adalah citra Landsat 8, dan untuk memperoleh citra iluminasi (IL) menggunakan data DEMNAS. Citra iluminasi matahari adalah cosine dari antara sudut yang terbentuk dari arah datangnya matahari dengan garis normal arah hadap dan kemiringan lereng (Vázquez-Jiménez et al, 2017). Iluminasi matahari didapat dengan menggunakan persamaan:

\section{$\mathrm{IL}=\cos \mathrm{a} \cos \theta+\sin { }_{-} \sin \theta \cos (\phi a-\phi 0) \ldots 2$}

Metode koreksi topografi yang digunakan adalah $C$ Correction dan SCS $+\mathrm{C}$. Metode $C$ Correc- tion adalah metode yang berasumsi linier tiap saluran dengan sudut iluminasi (IL) (Riano et al, 2003) dengan menggunakan persamaan:

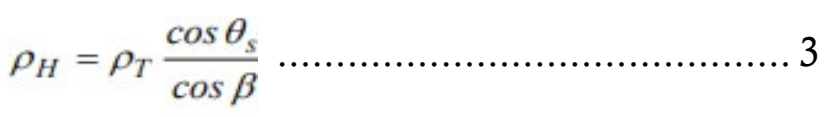

Metode SCS $+\mathrm{C}$ adalah metode dengan asumsi geometri daun dengan matahari diperhitungkan tegak (Soenen et al, 2005) dengan menggunakan persamaan:

$$
L_{n}=L \frac{\cos \alpha \cos \theta+\mathrm{C}}{\cos i+\mathrm{C}} .
$$

Metode koreksi topografi yang digunakan adalah $C$ Correction dan SCS $+C$ yang membutuhkan nilai koefisien $C$. Nilai Koefisien $C$ didapat melalui perhitungan empiris antara nilai piksel pantulan permukaan tiap saluran pada citra Landsat 8 dengan nilai piksel iluminasi matahari melalui analisis regresi. Nilai koefisien $C$ didapat dari hasil bagi antara nilai gradien B dengan A pada persamaan regresi yang dihasilkan.

\section{HASIL DAN PEMBAHASAN}

Pengolahan citra dalam penelitian ini dimulai dengan koreksi awan tipis. Koreksi awan tipis ini memanfaatkan saluran cirrus (saluran 9), karena saluran cirrus memiliki rentang 1.36-1.38 $\mu \mathrm{m}$, rentang tersebut memiliki kelebihan yaitu peka terhadap awan tipis yang terdiri dari kristal es dimana di saluran lain tidak memungkinkan untuk mendeteksinya (USGS, 2019). Pada saluran cirrus, awan berwarna cerah sementara daratan tampak gelap untuk area yang tidak tertutup awan dan uap air. Penggunaan saluran cirrus untuk menghilangkan awan tipis sangat efektif diterapkan pada saluran OLI dengan resolusi spasial 30m (Gao \& Li, 2017). Hasil dari koreksi awan tipis tidak terlalu mencolok karena untuk citra pada area kajian tampak bersih dan tidak ada gangguan awan tipis (Gambar 2).

Koreksi radiometrik citra adalah merubah DN ke nilai pantulan spektral objek, koreksi ini dilakukan beberapa tahapan dengan merubah nilai dari citra mentah berupa DN yaitu 16 bit dengan rentang 0- 65535 menjadi nilai pantulan spektral antara 0-1. Koreksi radiometrik dilakukan hingga koreksi ToA Reflectance.

Koreksi topografi membutuhkan dua data yaitu Landsat 8 yang telah terkoreksi radiometrik dan data citra iluminasi. Data citra iluminasi diperoleh dari proses hasil kemiringan lereng dan arah hadap lereng dari DEMNAS dan satuannya adalah radian (Gambar 3). Sebelum dilakukan 

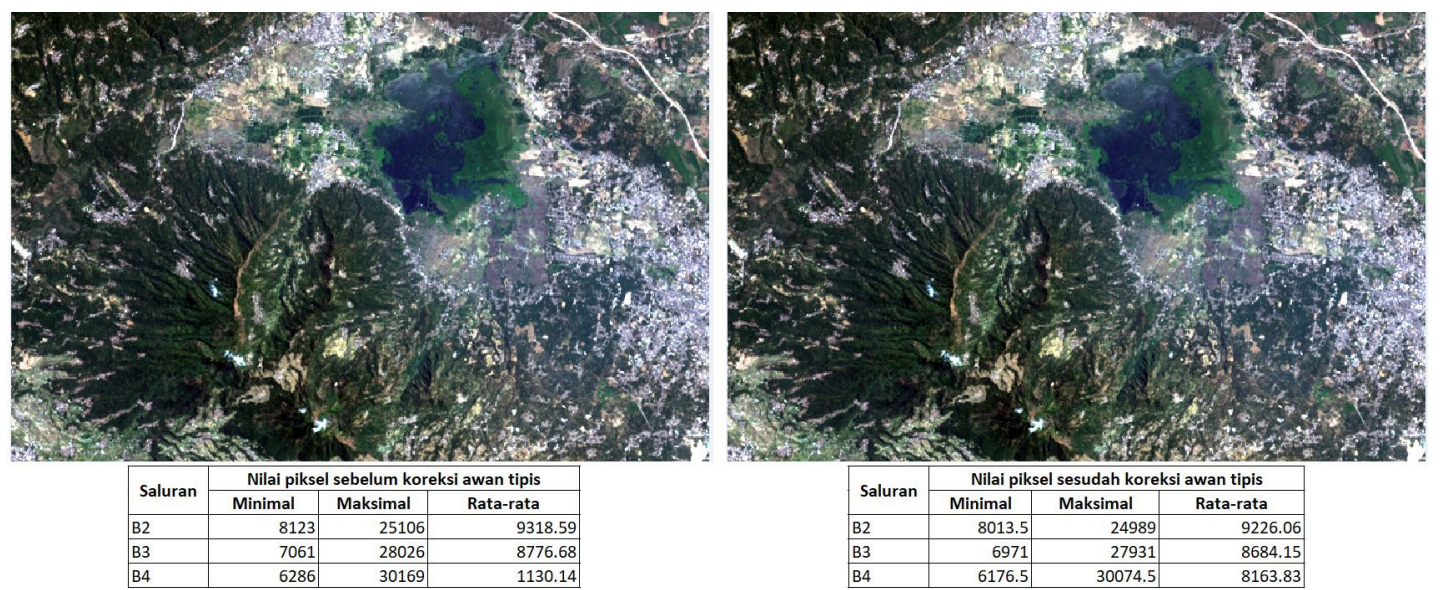

Gambar 2. Sebelum dan sesudah dikoreksi awan tipis
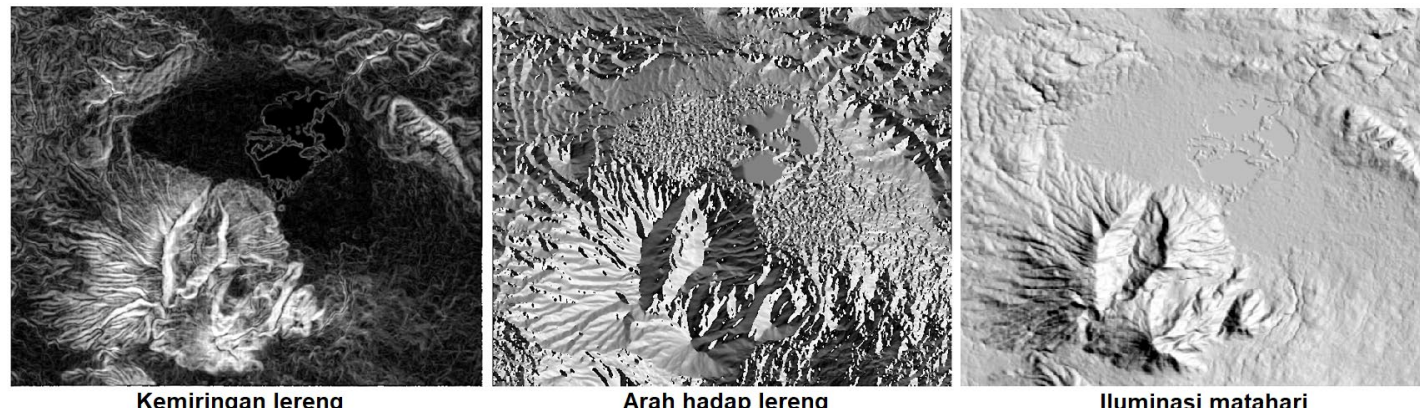

Gambar 3. Kemiringan lereng, arah hadap lereng dan iluminasi matahari area kajian

pemrosesan citra iluminasi, citra Landsat-8 dan DEMNAS harus disamakan resolusi spasialnya. Data DEMNAS yang memiliki resolusi spasial $8 \mathrm{~m}$ diubah (downscalling) menjadi $30 \mathrm{~m}$. Pembuatan citra iluminasi selain menggunakan data kemiringan lereng dan arah hadap lereng juga menggunakan parameter dari citra satelit Landsat-8 yaitu sudut azimuth matahari (sun azimuth) yang diambil dari metadata (.MTL). Hasil dari citra iluminasi adalah kenampakan topografi asli sesuai dengan kondisi arah datang sinar matahari pada saat akuisisi citra (Gambar 3).

Metode koreksi topografi yang digunakan da- lam penelitian ini adalah $C$ Correction dan SCS $+\mathrm{C}$, sehingga membutuhkan nilai koefisien $C$. Nilai koefisien $\mathrm{C}$ didapat dari rumus empiris yang dibentuk antara sudut iluminasi matahari (sebagai sumbu x yaitu variabel independen) dan nilai pantulan spektral saluran citra Landsat 8 terkoreksi atmosfer (sebagai sumbu y yaitu variabel dependen) dengan rumus regresi sederhana. Perhitungan empiris dilakukan dengan sampel penggunaan lahan yang sama (Gao et al, 2014). Pada penelitian ini menggunakan jumlah sebaran sampel yaitu 212 titik sampel yang tersebar dengan objek yang sama yaitu vegetasi keras (pepohonan) tetapi pada kemiringan

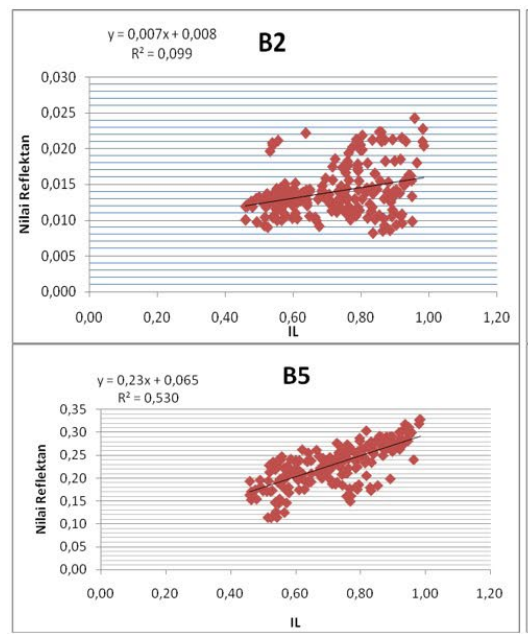

Gambar 4. Model regresi setiap saluran (B2-
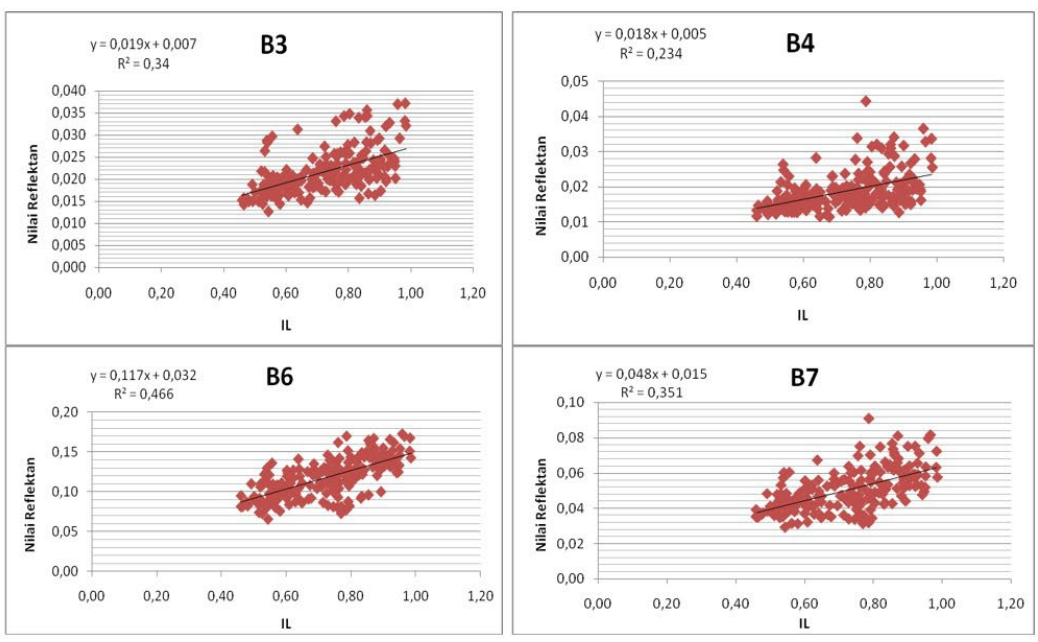
lereng yang beragam. Hasil dari pengambilan sampel tersebut adalah model regresi yang diterapkan pada setiap saluran (Gambar 4). Dari model regresi tersebut akan menghasilkan nilai koefisien $C$.

Nilai koefisen $C$ terbesar dari hasil pengolahan model regresi adalah saluran biru (band 2). Semakin panjang rentang gelombangnya maka nilai koefisien $C$ semakin sedikit, namun pada saluran SWIR 2 (band 7) justru nilainya lebih tinggi dari saluran 6 (saluran SWIR 1) (Tabel 1). Hal ini dikarenakan secara matematika koefisien $\mathrm{C}$ akan meningkatkan nilai penyebut pada persamaan koreksi topografi, sehingga terjadi peningkatan nilai piksel yang drastis pada nilai piksel yang kurang mendapatkan cahaya matahari (Meyer et al, 1993; Umarhadi, 2017).

Perbandingan visual citra terkoreksi topografi antara sebelum koreksi, dan sesudah koreksi adalah hilangnya efek bayangan lereng yang dihasilkan dari arah sudut matahari. Citra yang belum dikoreksi topografi akan terlihat jelas lekukan lereng yang dihasilkan sedangkan setelah dikoreksi lekukan akan hilang (Gambar 5). Koreksi topografi ini dilakukan untuk area yang berbukit guna meminimalisir bayangan yang mengganggu nilai pantulan spektral, sehingga didapat nilai pantulan asli dari objek tersebut. Secara visual kenampakan antara koreksi topografi $C$ Correction dan SCS+C hampir sama dalam mengurangi efek kenampakan topografi, namun jika dilihat lebih detail metode $C$ Correction kurang baik dalam melakukan koreksi topografi dibanding SCS $+\mathrm{C}$ (Gambar 6). Hal ini dapat dilihat jelas masih ada piksel yang lebih terang (overcorrection) pada lereng yang menghadap sinar matahari. Hasil ini senada dengan penelitian Vázquez-Jiménez et al (2017), Dong et al (2020), Soenen et al (2005) dan Fan et al (2014) bahwa koreksi topografi SCS+C cocok untuk diterapkan pada wilayah dengan tutupan lahan hutan.

Walaupun koreksi topografi sudah dilakukan, tetapi masih terdapat kenampakan efek topografi pada beberapa lokasi di area kajian. Kami berasumsi hal ini disebabkan citra iluminasi matahari yang digunakan berasal dari DEMNAS. Berdasarkan Julzarika \& Harintaka (2019), DEMNAS untuk wilayah sekitar Provinsi Jawa Tengah tidak berbentuk DSM (Digital Surface Model) maupun DTM (Digital Terrain Model), walaupun cenderung memiliki profil yang sama dengan DSM. Padahal data DEM berbentuk DSM lebih cocok digunakan dalam koreksi topografi karena merepresentasikan kenampakan permukaan penutup lahan (Umarhadi \& Danoedoro, 2019). Berdasarkan Hantson \& Chuvieco (2011), DEM yang disarankan untuk koreksi topografi adalah yang memiliki resolusi $1 / 3$ lebih detil dari citra yang akan dikoreksi, hal ini

Tabel 1. Tabel perbandingan nilai koefisien $C$ pada masing- masing saluran pada citra Landsat 8- OLI

\begin{tabular}{ccccccc}
\hline Koefesien & Band 2 & Band 3 & Band 4 & Band 5 & Band 6 & Band 7 \\
\hline C & 1.14 & 0.37 & 0.28 & 0.28 & 0.27 & 0.31 \\
\hline
\end{tabular}

(Sumber : Pengolahan Data, 2019)

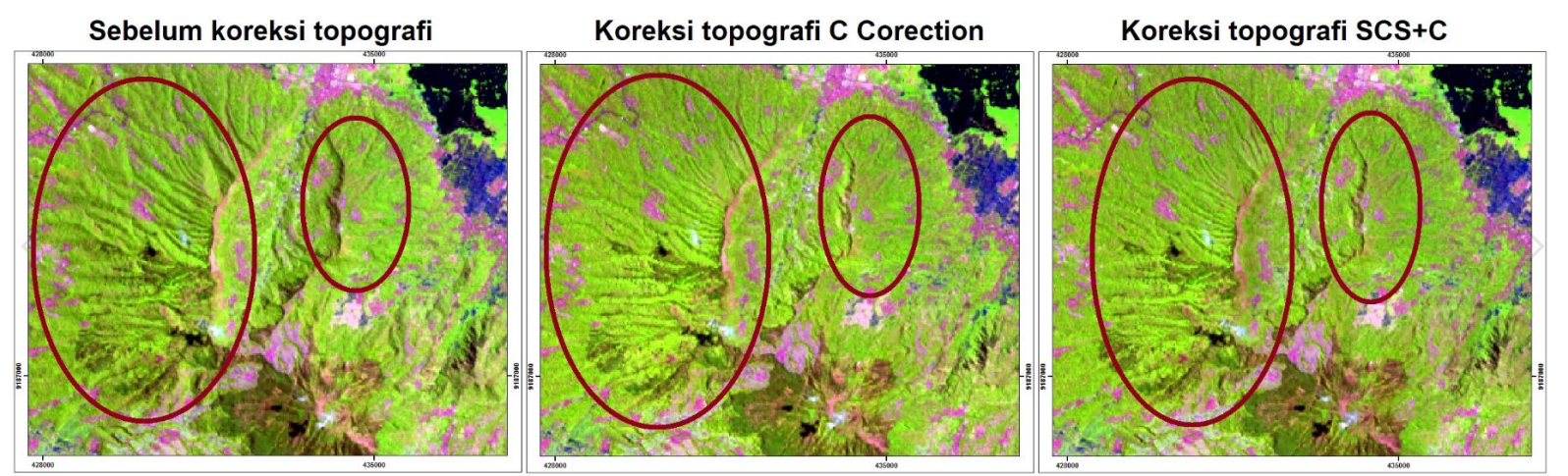

Gambar 5. Perbandingan visual citra Landsat-8, terlihat bahwa bayangan topografi hilang setelah dikoreksi topografi dimana hasil koreksi topografi C Correction terlihat overcorrection (terlalu terang)

Tabel 2. Tabel Perbandingan nilai standard deviasi setiap saluran Landsat-8

\begin{tabular}{ccccccc}
\hline & B2 & B3 & B4 & B5 & B6 & B7 \\
\hline Tanpa koreksi ToA & 0.0033 & 0.0048 & 0.0053 & 0.0447 & 0.0243 & 0.0115 \\
C Correction & 0.0033 & 0.0042 & 0.0046 & 0.0388 & 0.0204 & 0.0098 \\
SCS+C & 0.0032 & 0.0039 & 0.0043 & 0.0358 & 0.0187 & 0.0090 \\
\hline
\end{tabular}

(Sumber : Pengolahan Data, 2019) 
yang membuat DEMNAS lebih efisien ketimbang SRTM dan kontur RBI dalam koreksi topografi (Umarhadi \& Danoedoro, 2019).

Keberhasilan koreksi topografi dapat dilihat melalui nilai standar deviasi dari masing- masing saluran dan dibandingkan (Gao et al, 2014; Umarhadi \& Danoedoro, 2019). Semakin berkurang nilai standard deviasi pada koreksi topografi maka semakin berkurangnya efek iluminasi matahari pada lereng (Hantson \& Chuvieco, 2011; Gao et al, 2014; Umarhadi \& Danoedoro, 2019). Tabel perbandingan nilai standar deviasi diambil dari jumlah sampel 212 sehingga nilai yang dibandingkan adalah nilai untuk objek vegetasi (Tabel 2). Semakin rendah nilai standar deviasi menunjukkan semakin seragam nilai pantulan objek karena nilai yang mendekati 0 menandakan data sampel memiliki nilai mendekati rata- rata. Berdasarkan perbandingan nilai standar deviasi tersebut maka nilai koreksi topografi metode $\mathrm{SCS}+\mathrm{C}$ memiliki nilai terendah dibandingkan metode $C$ Correction dan tanpa koreksi topografi yang mana ini sebanding dengan kenampakan visualnya.

Penggunaan koreksi topografi sangat penting dalam kajian penginderaan jauh untuk bidang kehutanan. Hal ini dikarenakan koreksi topografi dapat meningkatkan akurasi data kehutanan pada dataran tinggi seperti biomassa, estimasi karbon serta perubahan tutupan hutan dalam skala luas (Pimple et al, 2017). Penelitian ini masih banyak terdapat limitasi sehingga perlu dilakukan banyak pengembangan. Pengembangan bisa dilakukan dengan menggunakan metode yang lebih beragam seperti metode Minnaert, SCS + C, Minnaert + SCS, dan VECA. Selain itu, pengembanan penelitian ini juga bisa dilakukan dengan menggunakan citra yang berbeda seperti Sentinel-2 yang memiliki resolusi spasial lebih besar yaitu $10 \mathrm{~m}$.

\section{KESIMPULAN}

Proses koreksi topografi akan semakin maksimal jika sebelumnya dilakukan proses koreksi awan tipis menggunakan saluran cirrus. Metode koreksi topografi yang paling baik pada penelitian ini adalah metode SCS $+C$ dilihat dari kenampakan visual dan memiliki nilai standard deviasi terendah dibandingkan dengan metode $C$ Correction. Sehingga untuk wilayah dengan dominasi tutupan lahan hutan maka metode SCS+C bisa direkomendasikan.

Saran untuk penelitian selanjutnya adalah menguji metode lain dan citra satelit yang lain seperti Sentinel-2. Metode koreksi topografi juga perlu diuji dilokasi yang memiliki tutupan lahan yang lebih beragam sehingga didapat rekomendasi metode koreksi topografi berdasarkan karakteristik wilayahnya.

\section{DAFTAR PUSTAKA}

Ardiansyah. (2015). Pengolahan Citra Penginderaan Jauh Menggunakan ENVI 5.1 dan ENVI LiDAR. Jakarta Selatan : Lasbig Inderaja Islim

Danoedoro, P. (2012). Pengantar Penginderaan Jauh Digital. Yogyakarta: Penerbit Andi.

Dianovita., Mahendra, R. (2014). Kajian ketelitian geometri citra Landsat 8 level 1T. Prosiding Seminar Nasional Penginderaan Jauh 2014

Dong, C., Zhao, G., Meng, Y., Li, B., Peng, B. (2020). The Effect of Topographic Correction on Forest Tree Species Classification Accuracy. Remote Sensing, 12(5), 787.

Fan, Y., Koukal, T., Weisberg, P.J. (2014). A sun-crown-sensor model and adapted C-correction logic for topographic correction of high resolution forest imagery. ISPRS J. Photogramm. Remote Sens. 2014, 96, 94-105.

Gao, B., Li, R. (2017). Removal of Thin Cirrus Scattering Effects in Landsat 8 OLI Images Using the Cirrus Detecting Channel. Settings Open Access Remote Sens. 2017, 9(8), 834

Gao, M., Zhao, W., Gong, Z., Gong, H., Chen, Z., Tang, X. (2014). Topographic Correction of ZY-3 Satellite Images and Its Effects on Estimation of Shrub Leaf Biomass in Mountainous Areas. Remote Sens. 6(4), 27452764

Hantson, S., Chuvieco, E. (2011). Evaluation of different topographic correction methods for Landsat imagery. International Journal of Applied Earth Observation and Geoinformation, 13(5), 691-700.

Hugli, H., Frei, W. (1983). Understanding Anisotropic Reflectance in Montainous Terrain. Photogramm. Eng. Remote Sens., 49, 671-683.

Hutami, R.T., Ariwibowo, Y., Widiarso, D.A. (2014). Studi Pendahuluan Daerah Prospek Panasbumi berdasarkan Data Manifestasi Panasbumi, Geokimia dan Isotop Fluida Panasbumi Komplek Gunung Telomoyo, Kabupaten Semarang Jawa Tengah. Geological Engineering E-Journal, 6(1) (2014)

Jaelani, L.M., Putri, R.A. (2017). Analysis of Land Cover Change of Lake Rawapening with Sentinel 1 - Synthetic Aperture Radar Data. IPTEK Journal of Proceedings Series, 3(6.)

Jensen, J. R. (2005). Introductory Digital Image Processing - A Remote Sensing Perspective, 3rd edition. Englewood Cliff, N.J.: Pearson Prentice Hall.

Julzarika, A., Harintaka. (2019). Indonesian DEMNAS: DSM or DTM?. IEEE Asia-Pacific Conference on Geoscience, Electronics and Remote Sensing Technology (AGERS)

Kurniawan, R., Danoedoro, P. (2017). Pengaruh Koreksi Radiometri Terhadap Akurasi Indeks Vegetasi Dalam Estimasi Biomass Di Atas Permukaan Tanah Pada Topograsi Bergunung Wilayah Gunung Api Lawu. Jurnal Bumi Indonesia, 6(2).

Meyer, P., Itten, K.I., Kellenberger, T., Sandmeier, S., Sandmeier, R. (1993). Radiometric corrections of topographically induced effects on Landsat TM data in an alpine environment. ISPRS Journal of Photogrammetry and Remote Sensing, 48(4), 17-28

Pimple, U., Sitthi, A., Simonetti, D., Pungkul, S., Leadprathom, K., \& Chidthaisong, A. (2017). Topographic correction of Landsat TM-5 and Landsat OLI-8 imag- 
ery to improve the performance of forest classification in the mountainous terrain of Northeast Thailand. Sustainability, 9(2), 258.

Riano, D., Chuvieco, E., Salas, J., Aguado, I. (2003). Assessment of Different Topographic Corrections in Landsat-TM Data for Mapping Vegetation Types. IEEE Transactions on Geoscience and Remote Sensing, 41(5).

Sanjoto, T. B., Sidiq, W. A. B. N., Nugraha, S. B. (2020). Land Cover Change Analysis To Sedimentation Rate Of Rawapening Lake. International Journal of GEOMATE, 18(70), 294-301

Soenen, S. A., Peddle, D. R., Coburn, C. A. (2005). SCS+C: A Modified Sun Canopy-Sensor Topographic Correction in Forested Terrain. IEEE Transactions on Geoscience and Remote Sensing, 43(9).

Umarhadi, D. A. (2017). Pengaruh Koreksi Radiometrik Topografi Terhadap Akurasi Pemetaan Kerapatan Kanopi Vegetasi Berkayu Menggunakan Citra Landsat-8 di Pegunungan Menoreh. Skripsi. Yogyakarta: Universitas Gadjah
Mada.

Umarhadi, D. A., Danoedoro, P. (2019). Correcting topographic effect on Landsat-8 images: an evaluation of using different DEMs in Indonesia. Proc.SPIE 11311, Sixth Geoinformation Science Symposium, 113110L (21 November 2019)

USGS. (2013). Landsat Processing Details. Diakses dari http:// landsat.usgs.gov pada Oktober 2019

USGS. (2019). How is the Landsat 8 Cirrus Band 9 used? Diakses dari https://www.usgs.gov/faqs/howlandsat-8-cirrus-band-9-used?qt-news_science_ products $=0$ \#qt-news_science_products pada Oktober 2019

USGS. (2019). Landsat 8 (L8) data users handbook. Department of the Interior US Geological Survey, LSDS-1574 Version 5.0

Vázquez-Jiménez, R., Romero-Calcerrada, R., Ramos-Bernal, R.N., Arrogante-Funes, P., Novillo, C.J. (2017). 